(C) Springer International Publishing Switzerland 2016

Roger J.R. Levesque

Encyclopedia of Adolescence

10.1007/978-3-319-32132-5_801-1

\title{
Financial Stress
}

Koen Ponnet ${ }^{1,2,3}$

(1)Department of Communication Studies, Ghent University, Ghent, Belgium

(2)Department of Communication Studies, University of Antwerp, Antwerp, Belgium

(3)Higher Institute for Family Sciences, Odisee, Brussels, Belgium

\section{Koen Ponnet}

Email: koen.ponnet@uantwerpen.be

\section{Without Abstract}

\section{Overview}

Financial stress is often associated with negative adolescent outcome, such as problem behavior, feelings of depression and anxiety. In this chapter, two primary hypotheses are explained about the reasons for socioeconomic status differences in rates of psychopathology and problem behavior of adolescents, namely the social selection and social causation hypothesis. Then, two major frameworks consistent with the social causation hypothesis, namely the family investment model and the family stress model, are described. Finally, evidence is provided that financial stress has direct as well as indirect effects on adolescents outcome.

\section{Socioeconomic Status and Adolescent Development}

Even in rich communities, growing up or living in poverty or at-risk-of-poverty remains a barrier for achieving success at school, at the workplace and in family life. Moreover, growing up and living with financial stress is detrimental to one's physical and mental health. Rates of psychopathology and various types of mental disorders (e.g., depression, anxiety) are higher among individuals from lowincome families than among individuals from middle- and high-income families (Ponnet 2014; Wadsworth and Achenbach 2005). In addition, adolescents and adults from low-income families are not only more likely to engage in offline risk behavior, such as aggressive behavior (Braveman et al. 2010) and substance abuse (Quon and McGrath 2015), but they are also more likely to engage in online risk behavior, like sexting (i.e., the sending of sexually explicit pictures through the Internet or mobile phone) (Van Ouytsel et al. 2014).

Considerable debate exists about the reasons for socioeconomic status differences in rates of psychopathology and risk behavior of adolescents. Two primary hypotheses have emerged. The first hypothesis, termed social selection, proposes that the traits and dispositions of parents influence their social status and the health and well-being of their offspring (Conger and Donnellan 2007; Mayer 1997). From this point of view, the observed associations between the socioeconomic status of parents and the developmental outcomes of adolescents are spurious because they are caused by a third 
variable. That is to say, both parental socioeconomic status and adolescents' development are proposed to emanate from certain personal characteristics that are directly transmitted from the parent to the adolescent (Conger et al. 2010b). The second hypothesis, referred to as the social causation hypothesis, posits that people with low socioeconomic status or at-risk-of-poverty develop psychological problems as a result of living with adversity (Gershoff et al. 2007; Wadsworth and Achenbach 2005). In the past decade, theorizing and research have shifted toward understanding the processes by which family income affects adolescents' development. There are two major frameworks consistent with the social causation hypothesis, namely the family investment model and the family stress model, which are described below.

\section{The Family Investment Model and the Family Stress Model}

The family investment model is rooted in economic principles of investments and posits that income is associated with successful development of adolescents as it enables parents to purchase the materials, experiences, and services that benefit the development and well-being of adolescents (Bradley and Corwyn 2002; Kiernan and Huerta 2008). From this perspective, low incomes adversely affect adolescents by reducing the quantity and quality of investments in adolescents, including time spent on child rearing. It is referred to as an investment model as it explains the income effects through the purchase of goods and services made by parents that can be used to invest in the human capital of their children. These investments include - among others - learning materials, adequate food, housing, clothing, and medical care (Conger and Donnellan 2007; Linver et al. 2002). Although, the family investment model provides a guide as to how low income might affect the level of material investments in adolescents, it does not address how economic circumstances might affect parent-child interactions (Kiernan and Huerta $\underline{2008}$ ).

In contrast, the family stress model (Conger and Conger 2002) is a framework which describes the mediating role played by family processes in linking economic disadvantage to adult and child adjustments. This model posits that income indirectly affects parents' psychological distress (e.g., depression) and creates interparental conflict due to feelings of financial stress. In other words, more than the objective experience of being poor, the subjective experience of economic disadvantage might lead to psychological distress (Barnett 2008; Conger and Donnellan 2007; Mistry et al. 2004). This subjective experience, referred to as financial stress, is often conceptualized as financial need (difficulties affording much more than the basics), financial burden (costs which impose a financial burden or struggle), financial insecurity (concerns about the future financial situation), or a combination of these concepts, and can be present in low-, middle-, and high-income families (Ponnet 2014). In low-income families, financial stress might derive, for example, from the inability to access resources such as wages that sufficiently cover the cost of available housing or child-related costs, while in high-income families, stress might derive from overspending or carrying a large debt. Although the quality of the financial stress experienced by a high-income father who is concerned about how he will pay the mortgage on his house might be different from that of a low-income father who has difficulties even affording the rent on a house, it can be expected that the subjective experience of both fathers impacts family and adolescent functioning (Mistry et al. 2008; Shek 2003). In its extended form, the family stress model posits that financial stress influences the development of adolescents through its effects on the experiences of parents (Conger et al. 2010a). As such, psychological distress caused by financial stress has an effect on interparental conflict and contributes to problems in parenting. This disruptive parenting subsequently mediates or explains the influence of 
parental distress and interparental conflict on problem behavior or other adolescent outcomes (Ponnet et al. 2014, 2015).

\section{Direct and Indirect Effects of Financial Stress on Adolescents Outcome}

While the family stress model posits that financial stress affects adolescents indirectly through its effects on the experiences of parents, there is, however, evidence that financial stress has both a direct and indirect relationship with adolescent adjustment (Conger et al. 2002; Taylor et al. 2004). ChaseLansdale and colleagues ( 2011) found that over time adolescents were more cognizant of their parents' social and economic affairs. As adolescents become aware of the shortage in the family's financial resources and contemplate the limits this imposes on their own prospects, hostility and externalizing problems may be more likely (Taylor et al. 2004, 2014). From this perspective, it can be assumed that the financial stress of parents with incomes at the lower end of the income distribution impacts adolescent adjustment both directly and indirectly because this financial stress relates to daily problems such as difficulties affording basic goods, which are clearly visible to adolescents. In contrast, the financial stress of middle- and high-income parents may only have indirect effects on the life of adolescents. Indeed, results of a recent study (Ponnet 2014) revealed that family stress processes operate in different ways for low-, middle-, and high-income families. In particular, the study demonstrated that in addition to a higher absolute level of financial stress in low-income families, a low-income mother's financial stress had a more detrimental impact in terms of more depressive feelings than mothers in middle income families. Furthermore, in low-income families, financial stress experienced by mothers and fathers had significant direct and indirect effects on problem behavior in adolescents, while in middle- and high-income families only significant indirect effects were found. However, the findings of the study also suggested that despite financial stressors, some families show resilience, and that this resilience may be more protective than in families with fewer stressors (Ponnet 2014). Studying financial stress in relation with the resilience of adolescents and their parents might be a direction for future research.

\section{Conclusion}

Several studies have shown that adolescents growing up in low-income families face many challenges that adolescents from more advantaged families do not. While the effects of financial stress on adolescent's lives are widely documented, the mechanism by which financial stress affects adolescents is less well understood. Evidence arising from the family stress model indicates that family stress processes operate in different ways in families with different income levels. Direct and indirect effects of financial stress on adolescent problem behavior were found in low-income families, while only indirect effects were found in middle- to high-income families.

\section{References}


Barnett, M. (2008). Economic disadvantage in complex family systems: Expansion of family stress models. Clinical Child and Family Psychology Review, 11(3), 145-161. doi:10.1007/s10567-0080034-z.

CrossRef PubMed PubMedCentral

Bradley, R. H., \& Corwyn, R. F. (2002). Socioeconomic status and child development. Annual Review of Psychology, 53, 371-399. doi:10.1146/annurev.psych.53.100901.135233.

CrossRef PubMed

Braveman, P. A., Cubbin, C., Egerter, S., Williams, D. R., \& Pamuk, E. (2010). Socioeconomic disparities in health in the United States: What the patterns tell us. American Journal of Public Health, 100, S186-S196. doi:10.2105/ajph.2009.166082.

CrossRef PubMed PubMedCentral

Chase-Lansdale, P., Cherlin, A. J., Guttmannova, K., Fomby, P., Ribar, D., \& Coley, R. (2011). Longterm implications of welfare reform for the development of adolescents and young adults. Children and Youth Services Review, 33(5), 678-688. doi:10.1016/j.childyouth.2010.11.016.

CrossRef PubMed PubMedCentral

Conger, R., \& Conger, K. (2002). Resilience in Midwestern families: Selected findings from the first decade of a prospective, longitudinal study. Journal of Marriage and Family, 64(2), 361-373. doi:10.1111/j.1741-3737.2002.00361.x.

CrossRef

Conger, R., \& Donnellan, M. (2007). An interactionist perspective on the socioeconomic context of human development. Annual Review of Psychology, 58, 175-199.

doi:10.1146/annurev.psych.58.110405.085551.

CrossRef PubMed

Conger, R., Wallace, L., Sun, Y., Simons, R., McLoyd, V., \& Brody, G. (2002). Economic pressure in African American families: A replication and extension of the family stress model. Developmental Psychology, 38(2), 179-193. doi:10.1037//0012-1649.38.2.179.

CrossRef PubMed

Conger, R., Conger, K., \& Martin, M. (2010a). Socioeconomic status, family processes, and individual development. Jounal of marriage and the family, 72, 685-704. doi:10.1111/j.17413737.2010.00725.x.

CrossRef 
Conger, R., Schofield, T., Conger, K., \& Neppl, T. (2010b). Economic pressure, parent personality and child development: An interactionist analysis. Historical Social Research-Historische Sozialforschung, 35(2), 169-194.

Gershoff, E., Aber, J., Raver, C., \& Lennon, M. (2007). Income is not enough: Incorporating material hardship into models of income associations with parenting and child development. Child Development, 78(1), 70-95. doi:10.1111/j.1467-8624.2007.00986.x.

CrossRef PubMed PubMedCentral

Kiernan, K., \& Huerta, M. (2008). Economic deprivation, maternal depression, parenting and children's cognitive and emotional development in early childhood. British Journal of Sociology, 59(4), 783-806. doi:10.1111/j.1468-4446.2008.00220_1.x.

CrossRef PubMed

Linver, M., Brooks-Gunn, J., \& Kohen, D. (2002). Family processes as pathways from income to young children's development. Developmental Psychology, 38(5), 719-734. doi:10.1037//00121649.38.5.719.

CrossRef PubMed

Mayer, S. (1997). What money can't buy: Family income and children's life changes. Cambridge, MA: Harvard University Press.

Mistry, R., Biesanz, J., Taylor, L., Burchinal, M., \& Cox, M. (2004). Family income and its relation to preschool children's adjustment for families in the NICHD study of early child care. Developmental Psychology, 40(5), 727-745. doi:10.1037/0012-1649.40.5.727.

CrossRef PubMed

Mistry, R., Lowe, E., Benner, A., \& Chien, N. (2008). Expanding the family economic stress model: Insights from a mixed-methods approach. Journal of Marriage and Family, 70(1), 196-209.

CrossRef

Ponnet, K. (2014). Financial stress, parent functioning and adolescent problem behavior: An actorpartner interdependence approach to family stress processes in low-, middle-, and high-income families. Journal of Youth and Adolescence, 43(10), 1752-1769. doi:10.1007/s10964-014-0159-y. CrossRef PubMed 
Ponnet, K., Van Leeuwen, K., \& Wouters, E. (2014). Examining mediating pathways between financial stress of mothers and fathers and problem behaviour in adolescents. Journal of Family Studies, 20(1), 66-78. doi:10.5172/jfs.2014.20.1.66.

CrossRef

Ponnet, K., Van Leeuwen, K., Wouters, E., \& Mortelmans, D. (2015). A family system approach to investigate family-based pathways between financial stress and adolescent problem behavior. Journal of Research on Adolescence, 25(4), 765-780. doi:10.1111/jora.12171.

CrossRef

Quon, E. C., \& McGrath, J. J. (2015). Community, family, and subjective socioeconomic status: Relative status and adolescent health. Health Psychology, 34(6), 591-601. doi:10.1037/hea0000135. CrossRef PubMed

Shek, D. (2003). Economic stress, psychological well-being and problem behavior in Chinese adolescents with economic disadvantage. Journal of Youth and Adolescence, 32(4), 259-266. doi:10.1023/a:1023080826557.

CrossRef

Taylor, R., Rodriguez, A., Seaton, E., \& Dominguez, A. (2004). Association of financial resources with parenting and adolescent adjustment in African American families. Journal of Adolescent Research, 19(3), 267-283. doi:10.1177/0743558403258828.

CrossRef

Taylor, R., Budescu, M., Gebre, A., \& Hodzic, I. (2014). Family financial pressure and maternal and adolescent socioemotional adjustment: Moderating effects of Kin social support in low income African American families. Journal of Child and Family Studies, 23(2), 242-254. doi:10.1007/s10826-012-9688-8.

CrossRef

Van Ouytsel, J., Van Gool, E., Ponnet, K., \& Walrave, M. (2014). Brief report: The association between adolescents' characteristics and engagement in sexting. Journal of Adolescence, 37, 13871391.

CrossRef PubMed

Wadsworth, M., \& Achenbach, T. (2005). Explaining the link between low socioeconomic status and psychopathology: Testing two mechanisms of the social causation hypothesis. Journal of Consulting and Clinical Psychology, 73(6), 1146-1153. doi:10.1037/0022-006x.73.6.1146.

CrossRef PubMed 
